\title{
Six sideways reflections on academic publishing
}

To examine the world is to reveal divergences, a range of potential polities, societies, and spaces, other to the conventional defined space of the research paper on the page. Yet it is possible to push at the edges of a research paper, and kick back against the standardization of scholarship. For variety and a breadth of scholarship is a symbolic and important characteristic of geography as a discipline. A present tragedy of publishing in the academic world is that, as international scholars, we are all increasingly pressured to produce research papers that meet certain externally imposed standards. This monitoring of academia through corporate/capitalist frameworks, can lead to the publishing of 'safe pieces', in place of texts that move disciplinary debates radically forward.

The Reflections section of this journal was set up with this exact issue in mind. In order to produce lively, critical, inventive interjections on current societal issues, and to open-out what is considered geographical endeavor through creative practice, and in essence, to subvert the research paper itself. It is dedicated to publishing Reflections on issues relevant to, and in, contemporary geographies, offering a space for empirically grounded as well as theoretically informed research. Pushing at the margins of the discipline is its aim, and its revolutionary agenda is to argue that the traditional craft of essay writing perhaps needs to be returned to the forefront of academia; essays that take a walk beyond the norm, other to the standardized research paper format of present (Forsdick 2005).

It seems that nowadays more regularly, rather than writing what we want to write as scholars we are instead - through an increasingly crude quantitative measurement - writing what we think we have to write. Yet, we suggest here, that research papers which subvert the traditional way-of-doingthings, have precisely the potential to become polemic, discipline changing, impactful pieces. One of the tragedies related to peer reviewed research papers is that, after publication, we may be left with a sense that our work has in some way been highjacked and tampered with, and the finished article does not accurately reflect what we wanted to say. Revision rounds, serving multiple purposes, can lead to a diluted version of the issue with which we sought to engage. Furthermore, as we look around the publishing landscape - as authors, editors, and reviewers - uneasy feelings arise, about enabling a narrowing, a cleansing, a streamlining of our research in print to fit the current corporate/capitalist agenda. In our view, this devalues much of the labor that goes into the research paper itself, before and beyond its processing in a journal, the time that goes into the gathering of data and analysis, and the placing of each word, each sentence, and each paragraph on the page.

These contradictions loom larger, and can be contextualized with reference to a longstanding and ever growing body of literature on neo-liberalization within academia, and as such, academic publishing (Castree \& Sparke 2000; Dowling 2008; Mountz et al. 2015). Ever more assessments and criteria, models and formula are creating a widening disconnection between university management and academic staff, and are indeed reducing the quality of academic research, preventing critical interrogations, critical thought and pedagogy, for fear of not fitting into this narrow model (Gray 2003). A research paper will not have impact, we worry, if it does not fit neatly into or is not suitable for framework assessments. These assessments, as such, seek to demarcate what geography is, what is geographical, what is correct or suitable geography. Thus, it is vital to critically interrogate them and to fight back against their neo-liberalization of the academy, for these assessments are in fact decreasing the breadth of geography, and in so doing, are reducing its quality, its excellence. This failure of an excellence framework, as such, to live up to its billing as a measure of excellence - rather instead prescribing a capitalist/corporate version of excellence - reveals that the model itself is essentially flawed. Unfortunately, we, as academics, are becoming overinvested in the idea of publish or perish, publish in this journal and not that journal, publish research papers and not book chapters, as a foundation stone of present-day scholarship. Consequently, our capacities to move beyond this neo-liberal formulation of academic publishing completely, are gradually diminishing.

In the editorial setting up the previous issue of Fennia, we sought to re-engage academics with another possibility, to suggest it does not have to be this way altogether, and to flesh-out an alternative publishing model, for there are subtle radical moves that can be made (for continuation, see the 
editorial of this issue, Kallio \& Hyvärinen 2017). Fennia has a specific and radical publication policy. It is non-profit, open access, in favor of open reviewing, and respecting of the rights of authors (under Creative Commons, with COPE, indexed in DOAJ and ESCI). Its aims and scope are broad, encompassing all fields of geography, with an attentiveness to northern dimensions, while topical and politicized issues arising from any part of the world and in any empirical context are particularly welcomed. The six sideways Reflections on publishing in this issue of Fennia, seek to build upon this initial editorial in the previous issue, on subtle radical moves in academic publishing. They offer an alternative to the staid mode of paper writing and the thorny issue of wanting to publish your work in academic journals, yet not wanting to reproduce the neo-liberalization of academia in printed form. Timely Reflections, they raise the problem with disseminating academic work through the straightjacketed research paper as a creative and critical form, and approach the problematic of the conventional publishing model in different ways.

We begin with a substantive piece on the measuring of research quality, quantitatively, from Michael Jones, based on his experience of editing the Norsk Geografisk Tidsskrift-Norwegian Journal of Geography (NGT-NJG), over a period of sixteen years. This is followed by a reflection on socially just publishing, from Simon Batterbury, which argues geographers can also be publishers, and offers a different experience of editing a free online journal, the Journal of Political Ecology. Following on from this reflection, the editors of the radical geography journal Human Geography seek to reclaim value from academic labor, offering routes around corporate/capitalist academic publishing. Weighing in on the nature of the problem, they reveal what they are doing in response as a journal, what successes they have had, and what challenges remain. Similarly, in reaction to the ever-increasing pressure placed on academics to publish within the neoliberal university, the editors of ACME: An International Journal for Critical Geographies state that scholars are increasingly declining to participate in peer review, and that this is the biggest obstacle they face as a journal. They argue persuasively that peer review should be considered as a form of mutual aid, which is rooted in an ethics of cooperation, perhaps other to the neoliberal university within which we operate as scholars. The final two Reflections which follow in this lively and timely debate, focus on the dominance of English language publishing in international academic work, and the broader geopolitics of knowledge production. Derek Ruez argues that contexts, approaches, and modes of knowledge are regularly devalued, placing concurrently critique on the Finnish and Nordic ranking systems, in line with the first reflection from Michael Jones. While Sara Fregonese offers a critical take on English as lingua franca, stating more reflection is needed in order for academic English not to become once again part of a disenfranchising process. It is perhaps this disenfranchising that we must give more thought to in a future issue of Reflections in Fennia, a Finnish geographical journal published in English, ensuring academic English does not become an excluding barrier, both in the writing and peer review stages of publishing.

A critical review essay brings this issue of Reflections to a close, in which Elisa Pascucci reflects upon and cites a far more complex reality than the one presented in the book, Refuge: transforming a broken refugee system (Betts \& Collier 2017). Pascucci states that fundamental research on refugees is missing from the controversial book, which asks the question: Can capitalism help refugees? A lack of engagement with historical and empirical precedents should not be overlooked here for Pascucci, for it is precisely this lack of engagement, which allows the authors to express an optimism about refugeefriendly capitalism.

Returning to the six Reflections on academic publishing that follow, to end, we would like to state precisely what it is that we are aiming at with this discussion. We aim here, to contribute to a critical discussion on the neo-liberal direction in which academia is travelling, among geographers and other scholars, between academics and political actors, globally and nationally, in institutional settings and scientific communities, in order to halt a corporate/capitalist creep into the academy. We welcome responses to the six Reflections published here, in future issues, whether that is through the articulation of alternative perspectives, or, in a form that builds upon the arguments and radical agenda presented. Suggestions for similar discussions on focal topics are encouraged and will be given a critical space within the Reflections section of Fennia in upcoming issues. We would like now, for you to critically engage with the vital reflections that follow, circulate them widely, and to repel the neo-liberalization of academia! 
JAMES RIDING

FENNIA REFLECTIONS EDITOR

KIRSI PAULIINA KALLIO

FENNIA EDITOR-IN-CHIEF

\section{REFERENCES}

Betts, A. \& Collier, P. (2017) Refuge: transforming a broken refugee system. Penguin Random House, London.

Castree, N. \& Sparke, M. (2000) Professional geography and the corporatization of the university: experiences, evaluations, and engagements. Antipode 32(3) 222-229. https://doi.org/10.1111/1467-8330.00131

Dowling, R. (2008) Geographies of identity: laboring in the 'neoliberal' university. Progress in Human Geography 32(6) 812-820. https://doi.org/10.1177/0309132507088032

Forsdick, C. (2005) De la plume comme des pieds: the essay as a peripatetic genre. In Forsdick, C. \& Stafford, A. (eds.) The modern essay in French: movement, instability, performance, 45-60. Peter Lang, Bern.

Gray, A. (2003) Cultural studies in Birmingham: the impossibility of critical pedagogy? Cultural Studies 17(6) 767-782. https://doi.org/10.1080/0950238032000150011

Kallio, K. P. \& Hyvärinen, P. (2017) A question of time - or academic subjectivity? Fennia 195(2) 121124. https://doi.org/10.11143/fennia.67834

Mountz, A., Bonds, A., Mansfield, B., Loyd, J., Hyndman, J. Walton-Roberts, M., Basu, R., Whitson, R., Hawkins, R., Hamilton, T. \& Curran W. (2015) For slow scholarship: a feminist politics of resistance through collective action in the neoliberal university. ACME: An International Journal for Critical Geographies 14(1) 1235-1259. 